\title{
軟岩トンネル掘削時の周辺岩盤の変形挙動
}

\section{北川 隆*・稲垣大介**}

軟岩トンネルを掘削した場合の周辺岩盤の変形挙動を知るための理論解析について考 察した. 岩盤の変形特性は軟化と残留を考慮したモデルとし, 強度特性はモール・クー ロンの破壊基準に従うものとした．岩盤物性值が変形挙動に及ぼす影響を調べた結果, 岩盤の強度特性が同じでも，それを構成する粘着力と内部摩擦角の組合せによって大き な違いがあることが明らかになった。 また，実際のトンネルの計測データと理論解を比 較したところ, 岩盤の変形挙動を概ね説明しうることが分かった.

Keywords : soft rock, strain-softening, elasto-plastic analysis, characteristic line

\section{1. 序論}

一般にトンネルや地下空洞を掘削すると, 周辺岩盤に は応力変化とそれに伴うひずみ変化や変形が生じる. と くに軟岩の場合, 塑性領域が発生して大きな内空変位を 伴うことも多い. したがって, 周辺岩盤の過大な変形や 塑性領域の広がりを制御するために，最適な形状と剛性 をもつ支保を選択する必要がある。すなわち，岩盤の力 学的特性を把握し, トンネルの寸法や掘削方法を考慮し た解析を行い, 周辺岩盤の応力変化や変位を予測するこ とができれば，合理的かつ経済的なトンネル掘削が可能 となる。

本報文は, このようなトンネル周辺岩盤の変形挙動に 関する理論解析について考察したものである. 解析方法 としては, いわゆる特性曲線法に着目し, 岩盤と支保の 相互作用を解析的, 定性的かつ定量的に求めることを目 的とした. 理論解析においては, 応力ーひずみ関係は線 形弾性でピークに達した後, 軟化から残留に至るモデル とした. また，体積ひずみの拘束圧依存性を解析に取入 れた。

岩盤物性が変形挙動に及ぼす影響を調べるためにパラ メトリック・スタディを実施した.さらに，実際のトン ネルで得られた計測データと理論值とを比較し, 考察を 加えた. その結果, 工学的に有用な知見が得られたので ここに報告する.

\section{2. トンネル掘削時の変形解析}

\section{（1）既往の研究}

トンネルを掘削した場合に, 周辺岩盤がどのような変 形挙動をするかについての理論的研究は, 古くから行わ

\footnotetext{
*正会員 工修 西松建設株式会社 土木設計部

（元105 東京都港区虎）門 1-20-10）

** 埼玉大学大学院理工学研究科 博士前期課程
}

れてきた. Daemen ${ }^{1)}$ は, 最初に理論解析で地盤内の空 洞周辺の弾塑性応力分布を示したのは Terzaghi ${ }^{2)}$ であ ると述べている.しかし, Terzaghiはトンネルの支保 設計への適用に関しては，一切言及しなかった.

トンネルの支保圧力という考え方を取り入れて初めて 理論解を示したのは, Fenner ${ }^{3)}$ である. Fenner は, 岩 盤の変形と支保荷重との関係は, 一般に特性曲線で表わ せることを提唱した. 後に $\mathrm{Pacher}^{4)}$ は, この特性曲線 にいくつかのトンネルから得られたデータを加味して, いわゆる Fenner-Pacher 曲線を提案した.

Rabcewicz $^{5)}$ は，今では日本のトンネル工事の標準工 法となっている NATM の基本的原理について, 前述の 'Fenner-Pacher 曲線を用いて説明し，ロックボルトな に゙の支保の設計方法を示した. 岡 $\left.{ }^{6}\right)$ は，この Rabcewicz の論文に準拠して，支保の作用効果と設計理論について 考察を加えた.その後, Kastner ${ }^{7)}$ は完全弾塑性型モデ ルを, Egger ${ }^{8)}$ は岩盤のダイレタンシーを考慮したモデ

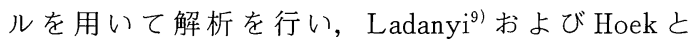
Brown ${ }^{10)}$ は，非線形破壊基準を解析に取り入れた。ま た Kaiser ${ }^{11)}$ は, 多くのトンネルの実測例から，岩盤の 進行性破壊に伴う弾性係数の低下が変形挙動に与える影 響が大きいと指摘した.

最近になって Brown et al. ${ }^{12)}$ が，ひずみ軟化特性と非 線形破壊基準を考慮し, さらに塑性体積変化の影響も取 り入れた新しい理論展開を行った. 我国においてもトン ネルの安定問題などに特性曲線を応用した, 土山ほか ${ }^{13)}$, 北川 ${ }^{14)}$, 佐藤ほか ${ }^{15)}$ などの研究が発表されている。 また, Hisatake et al. ${ }^{16)}$ は, 応力-ひずみ関係の非線形性と拘 束圧依存性を考慮した解析を実施している.

\section{（２）弾塑性理論解析}

ここでは, Brown et al. ${ }^{12)}$ の理論解析を基本として, 筆者らの新しい手法を加味した理論解析法を展開する. すなわち，破壞基準に関しては，Brown et al. が自ら 


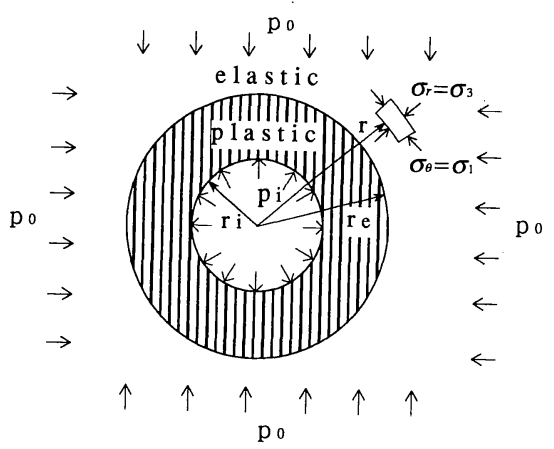

Fig.1 Tunnel model

提案する経験的基準を採用しているのに対して，日本の 軟岩を対象とする場合に，より適用性が高いと考えられ るモール・クーロン基準を採用した. さらに，ダイレイ タンシーを伴うひずみ関係が拘束圧によって変化するこ とを考慮した解析とした. なお，トンネル掘削問題では, 応力経路の影響が重要である。しかし，ここでは軟化か ら残留に至る応力ーひずみ関係に特に注目していること, および簡便な解析とすることの 2 つの理由によって応力 経路の影響は無視できるものとする.

対象とするトンネルと周辺岩盤のモデルを Fig.1 に示

す. 解析における基本的な仮定は次のとおりである.

・トンネル形状：半径 $r_{i}$ の円形とし，平面ひずみ，軸 対称問題亡する.

- 初期応力場：静水圧状態とし，その大きさを $p_{0}$ と する.

- 支保圧力：トンネル周辺に作用する等分布荷重 $p_{i}$ と等価とする.

・応力ーひずみ関係：弾性領域内では, 弾性係数 $E$, ポ アソン比レからなる線形弾性を示し, 塑性後は, ひずみ軟化挙動在経て最終 的には残留状態に至るものとする

(Fig.2).なお本論文では，ひずみお よび変位は, 全ひずみ (変位) から初 期応力による初期ひずみ（変位）を除 いたもの，すなわちトンネル掘削に よって生じるものを対象としている. また，圧縮ひずみ，圧縮応力を正とす る.

- 破 壊 基 準: 一般的なモール・クーロンの破壊基準 $(c, \phi)$ に従うものとし, 残留強度は $c_{r}, \phi_{r}$ で定められるものとする.

・塑 性 特 性：岩盤は破壊後体積膨張を起こすもの之 し，主ひずみ一体積ひずみの関係は，

Fig.3に示すトリリニア型とする.パ ラメーター $\alpha, h, f$ は, 実験データか ら求める.

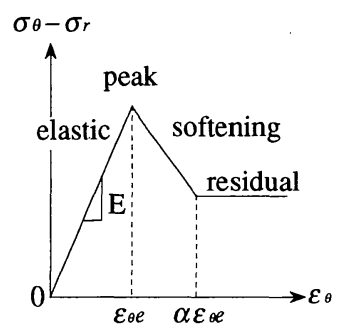

Fig.2 Stress-strain relationship
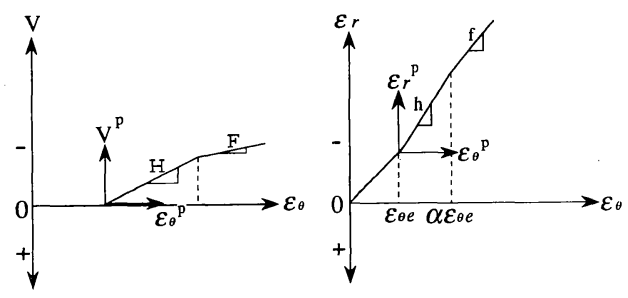

Fig.3 Plastic strain relationship

このような仮定に従うと，トンネル周辺岩盤の基本釣 合方程式は次式で与えられる.

$\frac{d \sigma_{r}}{d r}-\frac{\sigma_{\theta}-\sigma_{r}}{r}=0$

ここに, $\sigma_{r}$ : 半径方向主応力, $\sigma_{\theta}$ : 円周方向主応力, $r:$ 半径である.

式（1）を境界条件 $\left(r=r_{e}\right.$ において $\sigma_{r}=\sigma_{r e}, r=\infty$ に おいて $\left.\sigma_{r}=p_{0}\right)$ のもとに解く之次式が得られる.

$$
\begin{aligned}
& \sigma_{r}=p_{0}-\left(p_{0}-\sigma_{r e}\right)\left(r_{e} / r\right)^{2} . \\
& \sigma_{\theta}=p_{0}+\left(p_{0}-\sigma_{r e}\right)\left(r_{e} / r\right)^{2} .
\end{aligned}
$$

ここに, $\sigma_{r e}: r=r_{e}$ における半径方向主応力, $r_{e}:$ 弾 塑性境界半径, $p_{0}$ : 初期応力である.

また, 変位は弾性論から次式のように求められる.

$$
u=-(1+\nu) \cdot\left(p_{0}-\sigma_{r e}\right) r_{e}^{2} /(E r)
$$

ここに， $u$ : トンネル掘削によって生じる変位（半径 方向を正とする), $E$ : 弾性係数, レ：ポアソン比である. 式 (2) （4）は弾性領域（Fig.1の $r \geqq r_{e}$ の領域）の 応力と変位を表わしている.

さて，モール・クーロンの破壊基準は，周知のように 次式で表わされる.

$$
\sigma_{\theta}=\frac{1+\sin \phi}{1-\sin \phi} \cdot \sigma_{r}+2 c \cdot \frac{\cos \phi}{1-\sin \phi} .
$$

ここに, $\phi$ : 内部摩擦角, $c$ : 粘着力である.

式（2），（3)，（5）より，弾塑性境界 $\left(\boldsymbol{r}=\boldsymbol{r}_{\boldsymbol{e}}\right)$ に おける主応力差は, 次式となる.

$$
\begin{aligned}
& \sigma_{\theta e}-\sigma_{r e}=\frac{2 \sin \phi}{1-\sin \phi} \cdot \sigma_{r e}+2 c \cdot \frac{\cos \phi}{1-\sin \phi}=2\left(p_{0}-\sigma_{r e}\right) \\
& \therefore p_{i c r}=\sigma_{r e}=(1-\sin \phi) p_{0}-c \cdot \cos \phi \cdots \cdots \cdots \cdots \cdots(6) \\
& \text { ここに, } \sigma_{\theta e}: r=r_{e} \text { における円周方向主応力, } p_{i c r}:
\end{aligned}
$$
限界支保圧力 $\left(=\sigma_{r e}\right)$ である. すなわち, 支保圧力 $p_{i}$ 
が限界支保圧力 $p_{i c r}$ を下まわると周辺岩盤に塑性領域が 発生することになる.

今, $\varepsilon_{\theta}=\varepsilon_{\theta e}$ における $\tan \phi, c$ の值が, $\varepsilon_{\theta}=\alpha \cdot \varepsilon_{\theta e}$ にお ける $\tan \phi_{r}, c_{r}$ の值まで $\varepsilon_{\theta}$ に対して線形に減少すると 仮定すると，塑性領域（Fig.1の $r<r_{e}$ の領域）内の任 意点の応力は, 次式で表わされる.

$$
\sigma_{\theta}=\frac{1+\sin \bar{\phi}}{1-\sin \bar{\phi}} \cdot \sigma_{r}+2 \bar{c} \cdot \frac{\cos \bar{\phi}}{1-\sin \bar{\phi}} .
$$

ただし， $\varepsilon_{\theta e} \leqq \varepsilon_{\theta} \leqq \alpha \cdot \varepsilon_{\theta e}$ の時，

$$
\tan \bar{\phi}=\tan \phi+\left(\tan \phi_{r}-\tan \phi\right) \cdot \frac{\varepsilon_{\theta}-\varepsilon_{\theta e}}{(\alpha-1) \varepsilon_{\theta e}} .
$$

$$
\bar{c}=c+\left(c_{r}-c\right) \cdot \frac{\varepsilon_{\theta}-\varepsilon_{\theta e}}{(\alpha-1) \varepsilon_{\theta e}} .
$$

$\alpha \cdot \varepsilon_{\theta e}<\varepsilon_{\theta}$ の時,

$$
\tan \bar{\phi}=\tan \phi_{r}
$$

$\bar{c}=c_{r}$

ここに, $\alpha$ : ピーク強度時の主ひずみ $\varepsilon_{\theta}$ に対する残留 強度到達時の主ひずみ $\varepsilon_{\theta}$ の比 $(\mathbf{F i g} .2), \phi_{r}$ : 残留応力 時の内部摩擦角, $c_{r}$ : 残留応力時の粘着力である.

塑性領域を Fig.4に示すような多くの薄い環状リング に分割し, 弾塑性境界 $\left(r=r_{e}\right)$ 加ら始めて，各境界で の応力とひずみの関係から順々に内側に向かって繰り返 し計算を行い，それぞれの半径における応力と変位を求 める.

すなわち，まず初期条件 $(j=1)$ として次式を計算す る.

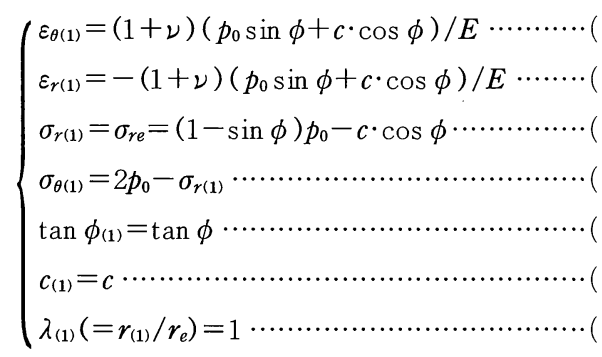

半径 $\boldsymbol{r}_{(j)}, \boldsymbol{r}_{(j-1)}$ におけるひずみ-変位関係は対称性か ら次式で表わされる.

$$
\left\{\begin{array}{l}
\frac{u_{(j-1)}}{r_{(j-1)}}=-\varepsilon_{\theta(j-1)} \cdots \\
\left(\frac{d u}{d r}\right)_{(j-1)}=-\varepsilon_{r(j-1)} \\
\frac{u_{(j)}}{r_{(j)}}=-\varepsilon_{\theta(j)} \cdots \ldots \\
\left(\frac{d u}{d r}\right)_{(j)}=-\varepsilon_{r(j)} \cdots
\end{array}\right.
$$

環状リングが十分薄いと仮定すると，近似的に次式が 成り立つ。

$$
\frac{u_{(j-1)}-u_{(j)}}{r_{(j-1)}-r_{(j)}}=\frac{1}{2}\left\{\left(\frac{d u}{d r}\right)_{(j-1)}+\left(\frac{d u}{d r}\right)_{(j)}\right\}
$$

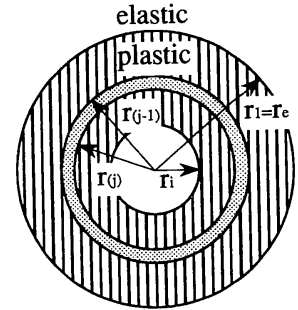

Fig.4 Annular ring in plastic zone

式（19）（22）を式（23）に代入すると

$$
\begin{aligned}
& \frac{r_{(j)}}{r_{(j-1)}}=\frac{2 \varepsilon_{\theta(j-1)}-\varepsilon_{r(j-1)}-\varepsilon_{r(j)}}{2 \varepsilon_{\theta(j)}-\varepsilon_{r(j-1)}-\varepsilon_{r(j)}} \\
& \therefore \lambda_{(j)}=\frac{r_{(j)}}{r_{e}}=\frac{2 \varepsilon_{\theta(j-1)}-\varepsilon_{r(j-1)}-\varepsilon_{r(j)}}{2 \varepsilon_{\theta(j)}-\varepsilon_{r(j-1)}-\varepsilon_{r(j)}} \lambda_{(j-1)} \\
& \text { いま, }
\end{aligned}
$$

$\Delta \varepsilon_{\theta(j)}=\varepsilon_{\theta(j)}-\varepsilon_{\theta(j-1)}=0.01 \cdot \varepsilon_{\theta(j-1)}$

とすると，

$$
\begin{aligned}
\varepsilon_{\theta(j)} & =\varepsilon_{\theta(j-1)}+\Delta \varepsilon_{\theta(j)} \ldots \ldots \ldots \ldots \ldots \\
\varepsilon_{r(j)} & =\varepsilon_{r(j-1)}-h \cdot \Delta \varepsilon_{\theta(j)} \ldots \ldots \ldots \ldots \\
\frac{u_{(j)}}{r_{e}} & =-\varepsilon_{\theta(j)} \cdot \frac{r_{(j)}}{r_{e}}=-\varepsilon_{\theta(j)} \cdot \lambda_{(j)}
\end{aligned}
$$

ここに, $h$ : 軟化応力時の円周方向塑性ひずみに対す る半径方向塑性ひずみの比例定数である (Fig.3 参照).

次に応力は次の手順で求める.

釣合方程式（1）に式（5）を代入すると次式が得ら れる.

$$
\frac{d \sigma_{r}}{d r}=\frac{1}{r}\left(\frac{2 \sin \phi}{1-\sin \phi} \sigma_{r}+2 c \frac{\cos \phi}{1-\sin \phi}\right)
$$

上式を $r_{(j-1))}, r_{(j)}$ で囲まれる環状リングに当てはめると 近似的に次式が成り立つ。

$$
\begin{aligned}
& \frac{\sigma_{r(j-1)}-\sigma_{r(j)}}{r_{(j-1)}-r_{(j)}}=\frac{2}{r_{(j-1)}+r_{(j)}}\left\{\frac{\sin \bar{\phi}_{a}}{1-\sin \bar{\phi}_{a}} \cdot\left(\sigma_{r(j-1)}+\sigma_{r(j)}\right)\right. \\
& \left.+2 \overline{c_{a}} \frac{\cos \bar{\phi}_{a}}{1-\sin \bar{\phi}_{a}}\right\}
\end{aligned}
$$

ここに

$\left\{\begin{array}{l}\tan \bar{\phi}_{a}=\frac{1}{2}\left(\tan \bar{\phi}_{(j-1)}+\tan \bar{\phi}_{(j)}\right. \\ \bar{c}_{a}=\frac{1}{2}\left(\bar{c}_{(j-1)}+\bar{c}_{(j)}\right) \ldots \ldots \ldots \ldots \ldots \ldots\end{array}\right.$

式 $(30)$ を $\sigma_{r(j)}$ について解くと

$\sigma_{r(j)}=\frac{1-2 a k}{1+2 a k} \sigma_{r(j-1)}-\frac{4 \overline{c_{a}} a k \cot \overline{\phi_{a}}}{1+2 a k}$

ここに,

$a=\frac{\sin \bar{\phi}_{a}}{1-\sin \bar{\phi}_{a}}$

$k=\frac{r_{(j-1)}-r_{(j)}}{r_{(j-1)}+r_{(j)}}$

式（5）加 


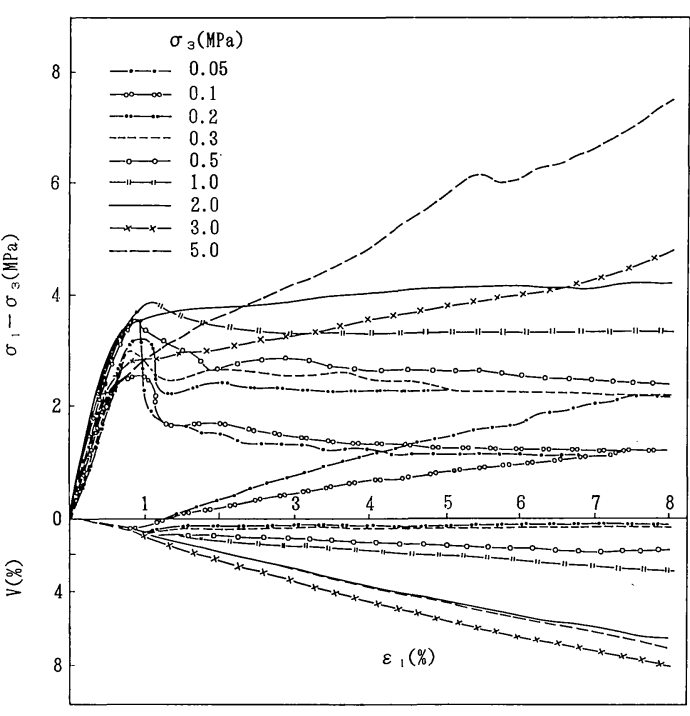

Fig.5 Stress-strain relationship of typical mudstone ${ }^{17)}$

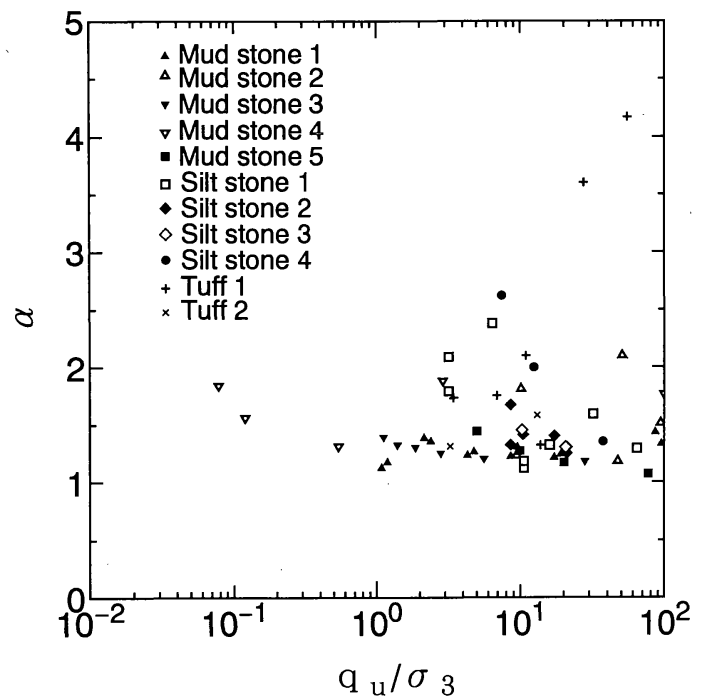

Fig.6 Relationship between $q_{u} / \sigma_{3}$ and $\alpha$

$\sigma_{\theta(j)}=\frac{1+\sin \bar{\phi}_{(j)}}{1-\sin \bar{\phi}_{(j)}} \sigma_{r(j)}+\frac{2 \bar{c}_{(j)} \cos \bar{\phi}_{(j)}}{1-\sin \bar{\phi}_{(j)}}$

ここで $\sigma_{r(j)}>p_{i}$ (支保圧力) であれば， $j=j+1$ とし て次の内側の環状リングの計算に移ることになる.

繰り返し計算の途中で $\varepsilon_{\theta(j)}>\alpha \cdot \varepsilon_{\theta(1)}$ が成立した場合に は，残留領域の計算になる．すなわち，

$$
\bar{\phi}_{(j)}=\phi_{r} \quad \bar{c}_{(j)}=c_{r}
$$

となり，式 $(27)$ の代わりに次式で $\varepsilon_{r(j)}$ を求めること になる。

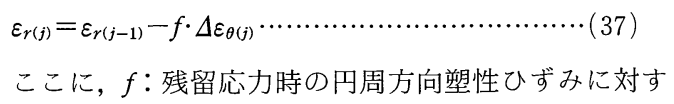

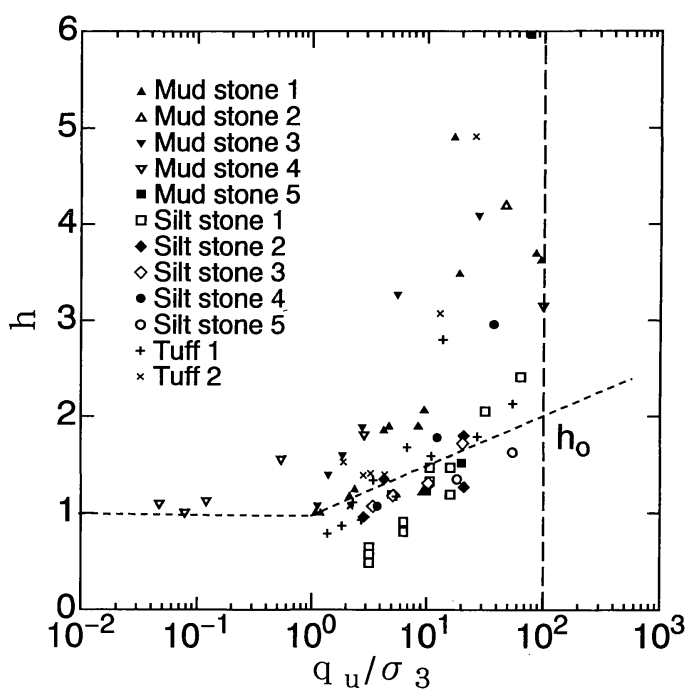

Fig.7 Relationship between $q_{u} / \sigma_{3}$ and $h$

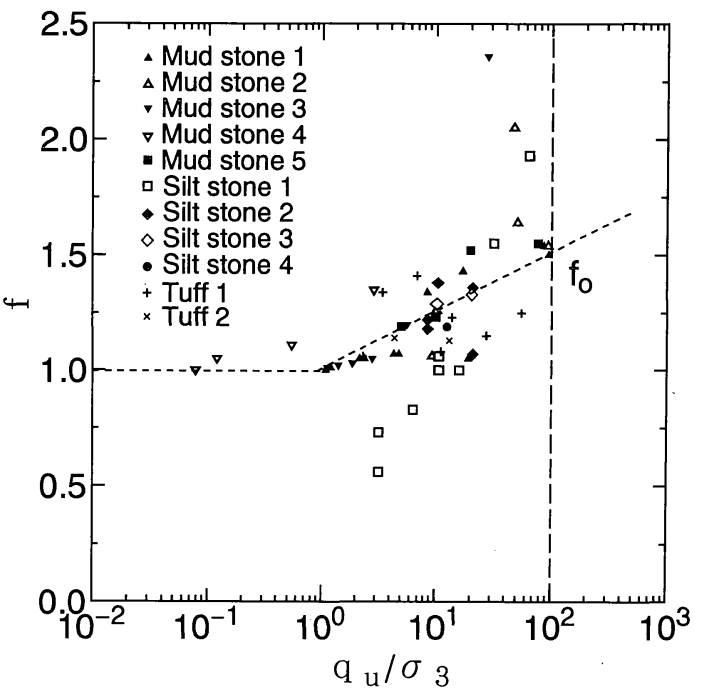

Fig.8 Relationship between $q_{u} / \sigma_{3}$ and $f$

る半径方向塑性ひずみの比例定数である (Fig.3 参照). 以上の繰り返し計算は, $\sigma_{r(j)}<p_{i}$ となった時点で終了 する. また, 弾塑性境界半径 $r_{e}$ は, 最後の $\lambda_{(j)}$ を用い て次式で求める.

$$
r_{e}=\frac{r_{(j)}}{\lambda_{(j)}}=\frac{r_{i}}{\lambda_{(j)}}
$$

\section{3. 変形挙動に及ぼす岩盤物性値の影響}

ここでは, 前章に述べた解析手法を用いて, 本研究で 対象としている軟岩の物性値, とくに強度特性がトンネ ルの変形挙動に与える影響について考察する.

\section{(1) 解析条件}

一般に軟岩では, 塑性化に伴うダイレイタンシー特性 
Table 1 Parameters for analysis

\begin{tabular}{l}
\hline$E / p_{0}=100 q_{u} / p_{0}$ \\
\hline$c / p_{0}=0.1 \sim 5.0$ \\
$c_{r} / p_{0}=0.01 \sim 0.5$ \\
\hline$\phi=10 \sim 50^{\circ}$ \\
$\phi_{r}=5 \sim 25^{\circ}$ \\
\hline$\nu=0.25$ \\
\hline$\alpha=1.5$ \\
$h_{0}=2.0$ \\
$f_{0}=1.5$ \\
\hline$r_{i}=4.0 \mathrm{~m}$ \\
\hline
\end{tabular}

が重要である．Fig.5 は，典型的な軟岩である富岡層泥 岩の圧密排水三軸圧縮試験結果 ${ }^{17)}$ である. 拘束圧の違い によって, 応力ーひずみ曲線や塑性体積ひずみ挙動が変 化することが分かる.

数多くの軟岩の室内三軸圧縮試験デー夕から, 解析に 必要な塑性パラメーター $\alpha, h, f$ 値を求めて整理した 結果 ${ }^{18)}$ を Fig.6〜 Fig.8に示す. いずれも，データはか

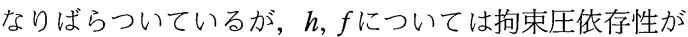
見られる。しかし，拘束圧 $\sigma_{3}$ が一軸圧縮強度 $q_{u}$ を上ま わると，ほぼ一定值に収束する傾向が見られる，そこで 塑性パラメーターのうち $\alpha$ は Fig.6 から一定值 $(=1.5)$ とし， $h, f$ は Fig.7, Fig.8に示すような拘束圧依存性 を考慮したバイリニア直線で近似できるものとする。な お, $q_{u} / \sigma_{3}=10^{2}$ の時の $h, f$ の值を $h_{0}, f_{0}$ とする.

トンネルの変形は，岩盤物性だけでなく作用荷重に よって大きな影響を受ける，したがって，岩盤の一軸圧 縮強度と初期応力の比である地山強度比 $\left(=q_{u} / p_{0}\right)$ に 着目して解析を実施する．解析条件を Table 1 に示す。 なお, 応力の次元をもつ物性値は, 初期応力 $p_{0}$ で除し て無次元化して取扱うものとする。 また，文献 ${ }^{19}$ から $E$ $=100 q_{u}$ とし $, c_{r}=0.1 c, \phi_{r}=\phi / 2$ とする.

\section{(2) 解析結果}

まず, 地山強度比そのものが特性曲線に与える影響に ついて考察する. Fig.9 は, $\phi=30^{\circ}$ の場合の地山強度比 と特性曲線との関係を示したものである．特性曲線上に は，岩盤の応力状態が軟化から残留に変化する位置を黒 丸で示している. この変化点を境界にして, ひずみ $\varepsilon(=$ 一 $\left.u_{i} / r_{i}\right)$ が急激に大きくなっていることが分かる。た だし， $u_{i}$ はトンネル側壁の変位である.

地山強度比の影響をさらに詳しく見るために，横軸に 地山強度比, 縦軸に無支保, すなわち支保圧力 $p_{i}=0$ の 場合のひずみをとって示したものがFig.10である。パ ラメーターには, 内部摩擦角 $\phi$ をってある. 各々の $\phi$ に対して，地山強度比が 2.0 以下になると，岩盤は弾 性状態加ら塑性状態に移行し，地山強度比が 1.5 を下ま

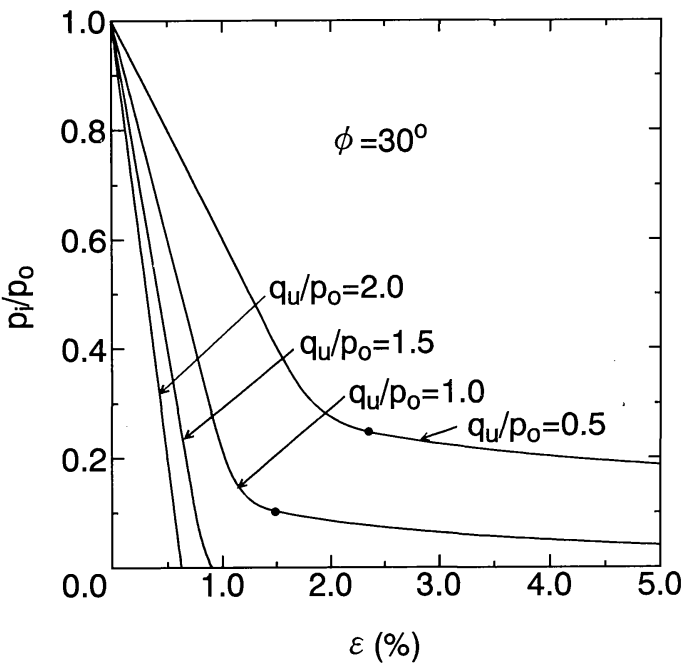

Fig.9 Characteristic lines $\left(\phi=30^{\circ}\right)$

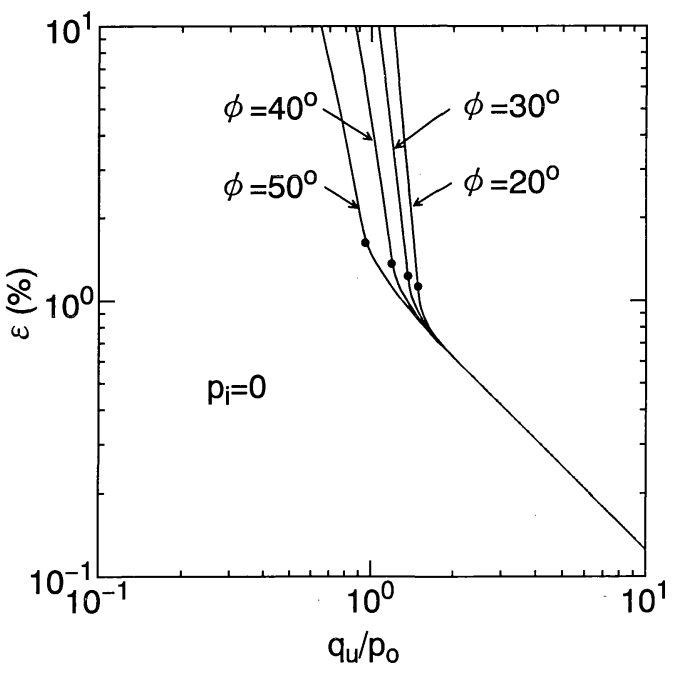

Fig.10 Relationship between $q_{u} / p_{0}$ and $\varepsilon\left(\phi=20 \sim 50^{\circ}\right)$

わると急激にひずみが増大することが分かる。これは， 岩盤の応力状態が軟化から残留へと変化するためと考え られる。

Fig.9 と同様の関係を $c / p_{0}$ を一定值 $(=0.4)$ にして 示したのがFig.11 である. また，Fig.10 と同様の関係 を $c / p_{0}$ をパラメーターにして示したのがFig.12であ る. どちらも前述と同様の傾向を示しており， $\phi$ あるい は $c / p_{0}$ の值が岩盤の変形挙動に少なからぬ影響を与え ることが分かる.

次に, 地山強度比が一定の場合に, 内部摩擦角 $\phi$ が特 性曲線に与える影響を調べた。地山強度比が 1.2 の場合 を示すと Fig.13のようである．やはり，軟化から残留 への変化点を境界にして，ひずみが急増することが分か る. そこで内部摩擦角の影響を詳しく考察するため, 横 


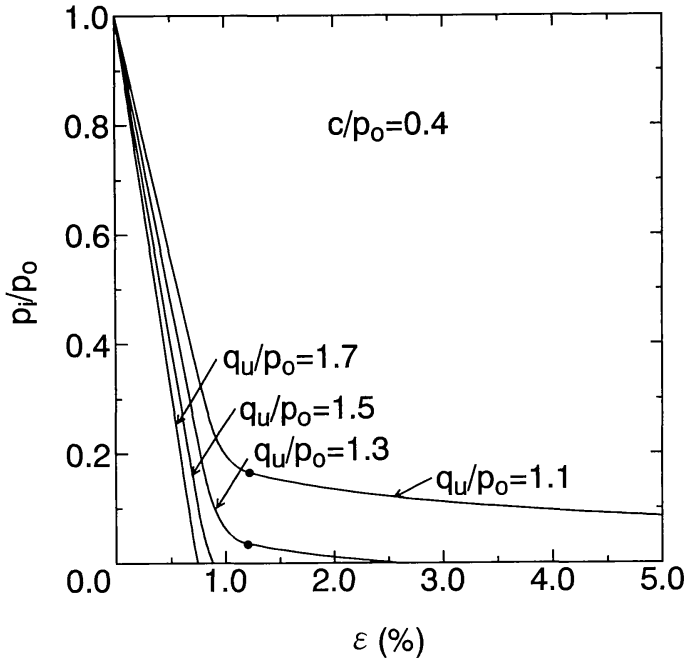

Fig.11 Characteristic lines $\left(c / p_{0}=0.4\right)$

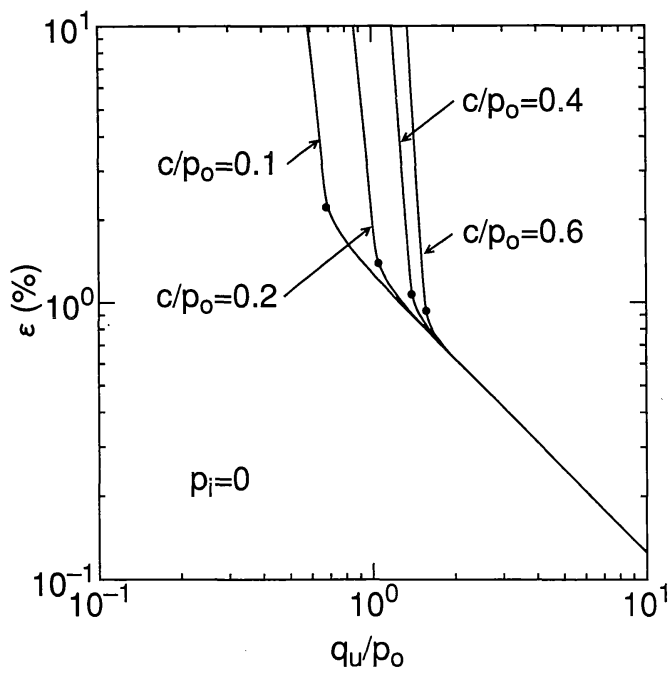

Fig.12 Relationship between $q_{u} / p_{0}$ and $\varepsilon\left(c / p_{0}=0.1 \sim 0.6\right)$

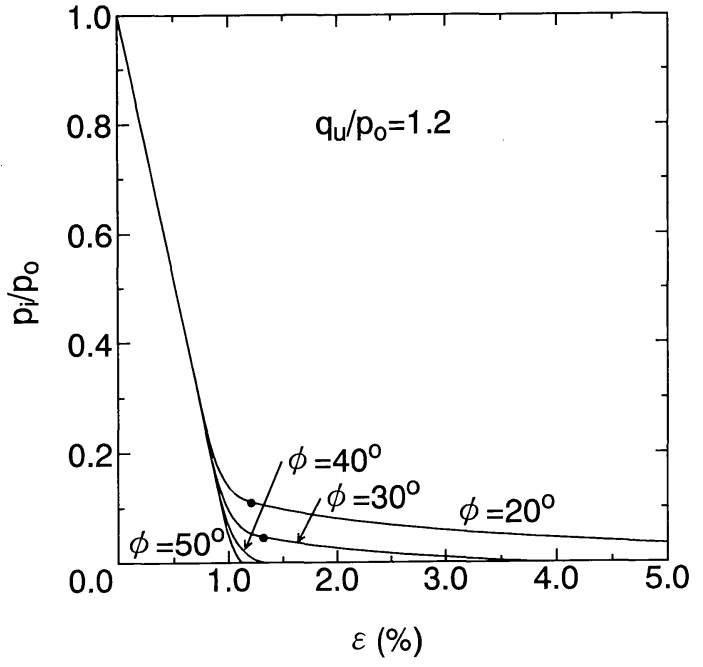

Fig.13 Characteristic lines $\left(\phi=20 \sim 50^{\circ}\right)$

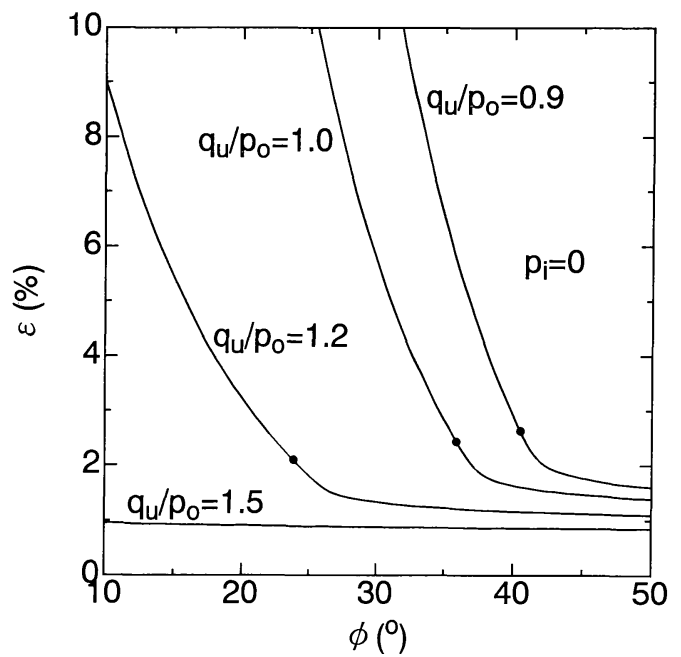

Fig.14 Relationship between $\phi$ and $\varepsilon$
軸に内部摩擦角をとり, 縦軸に無支保, すなわち支保圧 力 $p_{i}=0$ の時のひずみをとって示したのが Fig.14であ る。一定の地山強度比であるにもかかわらず，その值が 1.5 を下まわると内部摩擦角の減少に伴ってひずみが急 増することが分かる.

Fig.13 と同様の関係を粘着力 $c / p_{0}$ をパラメーターに して示したのが，Fig.15である．また，Fig.14 と同様 の関係を横軸を粘着力 $c / p_{0}$ として示したのが Fig.16 で ある. どちらも前述と同様の傾向を示しており，岩盤の 強度特性, すなわち $\phi$ あるいは $c / p_{0}$ の值が変形挙動に 少なからぬ影響を与えることがここでも明らかになっ た.

以上の考察を総括すると，一軸圧縮強度あるいは地山 強度比が同じでも，それを構成する粘着力と内部摩擦角
の組合せが岩盤の変形挙動に大きく影響することが明ら かになった. 従って, トンネルの変形解析に際しては, これらのことを十分に考慮する必要があると言える.

\section{4. 計測値と解析値の比較}

本章では，過去のトンネル工事例における数多くの計 測データと, 前章までに述べた解析方法による解析值と の比較を行い, 本解析手法の有用性を示す.

(1) 計測データ

トンネルの掘削によって地盤が変形する挙動は, 地盤 の力学特性および作用する゙荷重の大きさが重要な要因と なる. そこで, 数多くの計測データ 20),21),24) から内空変位, 天端沈下，およびその計測位置での地山強度比との関係 が明らかなものを Fig.17に示す.ここに，横軸は地山 


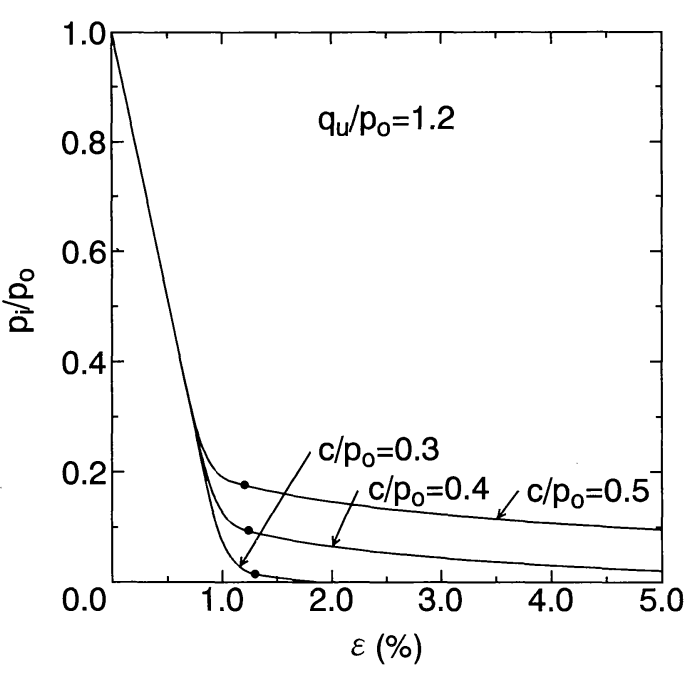

Fig.15 Characteristic lines $\left(c / p_{0}=0.3 \sim 0.5\right)$

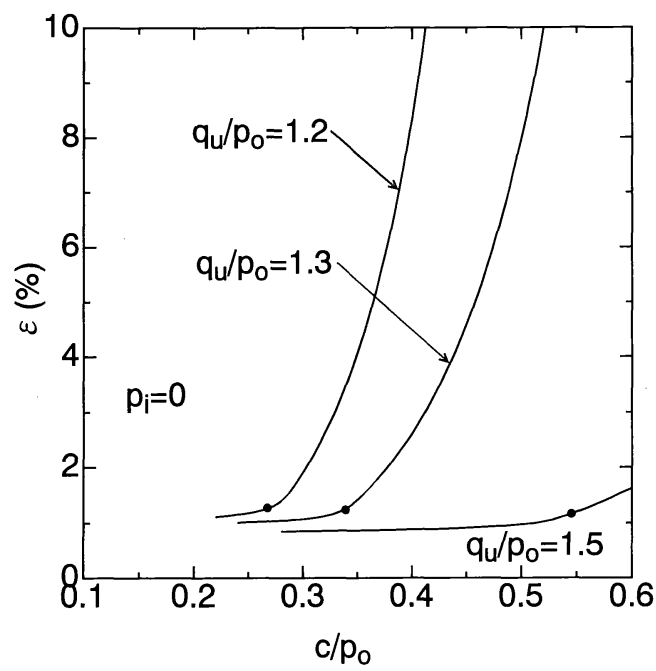

Fig.16 Relationship between $c / p_{0}$ and $\varepsilon$

強度比，縦軸は計測された内空変位等から計算で求めた ひずみ $\varepsilon\left(=-u_{i} / r_{i}\right)$ である.これらのデー夕は, 当然 のことながら種々の支保が施工されて, 地山の押出し力 とバランスした時点での值であるから, 同じ地山強度比 でもひずみの大小にはかなりの幅がある.

それぞれの地山強度比に対するひずみの上限值に注目 すると，これらは支保の設置が遅かったか，支保の剛性 が小さかった場合等と考えられる.しかし，いずれの場 合でも支保の能力が最大限に発揮されてバランスした極 限值を示していると解釈できる。試みに，それぞれの地 山強度比の上限值を結ぶと図中の上の点線のようである. この曲線は, 地山強度比が 1.0 2.0 以下になるとひずみ 量が増大する傾向を示している．これは，一般に地山強 度比が限界值の 2.0 を下まわると押出しが発生すると理

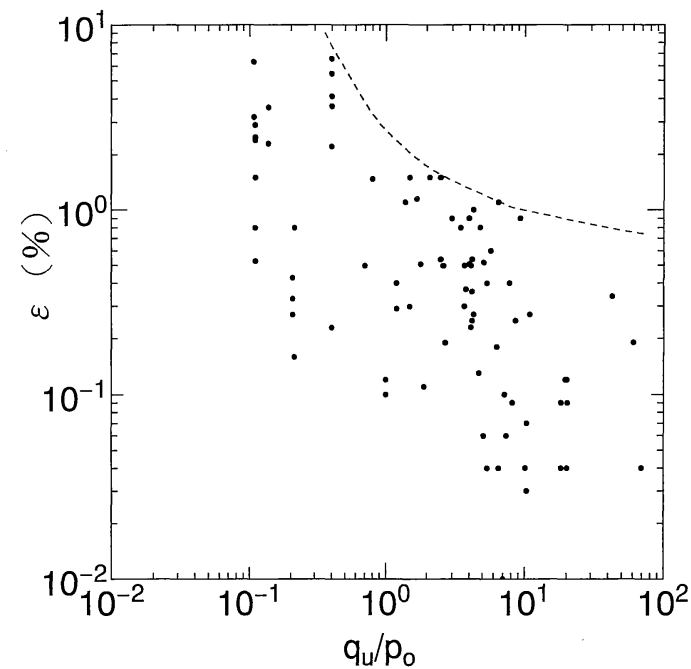

Fig.17 Relationship between ground strength ratio and measured strain

Table 2 Rock mass classification and properties

\begin{tabular}{l|c|c|c|c}
\hline \multicolumn{1}{c|}{ JHPC* $^{*}$} & C I & C II & D I & D II \\
\hline$V_{\mathrm{p}}(\mathrm{km} / \mathrm{s})$ & $2 \sim 3.5$ & $2 \sim 3.5$ & $1.5 \sim 3$ & $1 \sim 2$ \\
\hline Steel Arch & - & $\begin{array}{c}\mathrm{H}-125 \\
@ 1.2 \mathrm{~m}\end{array}$ & $\begin{array}{c}\mathrm{H}-125 \\
@ 1.0 \mathrm{~m}\end{array}$ & $\begin{array}{c}\mathrm{H}-150 \\
@ 1.0 \mathrm{~m}\end{array}$ \\
\hline Shotcrete & $t=10 \mathrm{~cm}$ & $t=10 \mathrm{~cm}$ & $t=15 \mathrm{~cm}$ & $t=20 \mathrm{~cm}$ \\
\hline Rock Bolts & $\begin{array}{c}l=3.0 \mathrm{~m} \times \\
1.5 \mathrm{~m}\end{array}$ & $\begin{array}{c}l=3.0 \mathrm{~m} \\
1.5 \\
1.2 \mathrm{~m}\end{array}$ & $\begin{array}{c}l=4.0 \mathrm{~m} \times \\
1.1 \mathrm{~m}\end{array}$ & $\begin{array}{c}l=4.0 \mathrm{~m} \\
1.2 \times \\
1.0 \mathrm{~m}\end{array}$ \\
\hline CRIEPI** & $\mathrm{C}_{\mathrm{H}}$ & $\mathrm{C}_{\mathrm{M}}$ & $\mathrm{C}_{\mathrm{L}}$ & $\mathrm{D}$ \\
\hline$V_{\mathrm{p}}(\mathrm{km} / \mathrm{s})$ & $3.0 \sim 4.0$ & $1.5 \sim 3.0$ & $\leqq 1.5$ & $\leqq 1.5$ \\
\hline$E_{0}(\mathrm{MPa})$ & $2000 \sim 5000$ & $500 \sim 2000$ & $\leqq 500$ & $\leqq 500$ \\
\hline$c(\mathrm{MPa})$ & $2.4 \sim 4.0$ & $1.0 \sim 2.4$ & $0.4 \sim 1.0$ & $\leqq 0.4$ \\
\hline$\phi\left(^{\circ}\right)$ & $45 \sim 55$ & $38 \sim 45$ & $30 \sim 38$ & $15 \sim 30$ \\
\hline$q_{u}(\mathrm{MPa})$ & $12 \sim 25$ & $4 \sim 12$ & $1.5 \sim 4$ & $\leqq 1.5$ \\
\hline
\end{tabular}

* JHPC : Japan Highway Public Corporation

** CRIEPI : Central Research Institute of Electric Power Industry

論的，経験的に言われていることと良く一致する.

\section{（2）岩盤分類と解析用物性値}

道路公団の設計要領 ${ }^{22)}$ では, 岩盤分類とそれに対応し た支保パターンを設定している．ここでは，道路公団の 岩盤分類と支保パターンに基づくモデルトンネル周辺の 最大ひずみを解析で求めるための岩盤物性值と支保剛性 を定める.

道路公団の岩盤分類および支保パターンを Table 2 に 示す. Table 2 には，道路公団の岩盤分類と概略の対応 が付けられている電力中央研究所の岩盤分類も示してい る. 岩盤の変形特性亡強度特性は, 北川 ${ }^{14)}$, 菊地 ${ }^{23)}$, 瀬 崎 ${ }^{24)}$ などの研究を参考にした。一軸圧縮強度 $q_{u}$ は, $c$ と 
Table 3 Properties for analysis

\begin{tabular}{|c|c|c|c|c|}
\hline JHPC* & C I & $\mathrm{C}_{\text {II }}$ & D I & $\mathrm{D}$ II \\
\hline$E(\mathrm{MPa})$ & 3500 & 1200 & 300 & 100 \\
\hline$\nu$ & 0.25 & 0.25 & 0.25 & 0.25 \\
\hline$q_{u}(\mathrm{MPa})$ & 18 & 8 & 3 & 0.8 \\
\hline$c(\mathrm{MPa})$ & 3.2 & 1.7 & 0.7 & 0.2 \\
\hline$\phi\left({ }^{\circ}\right)$ & 50 & 42 & 34 & 22 \\
\hline$\alpha$ & 1.5 & 1.5 & 1.5 & 1.5 \\
\hline$h_{0}$ & 2.0 & 2.0 & 2.0 & 2.0 \\
\hline$f_{0}$ & 1.5 & 1.5 & 1.5 & 1.5 \\
\hline$c_{r}(\mathrm{MPa})$ & 0.32 & 0.17 & 0.07 & 0.02 \\
\hline$\phi_{r}\left({ }^{\circ}\right)$ & 25 & 21 & 17 & 11 \\
\hline$r_{i}(\mathrm{~m})$ & 4.0 & 4.0 & 4.0 & 4.0 \\
\hline$k_{s}(\mathrm{MPa})$ & - & 130 & 156 & 207 \\
\hline$k_{c}(\mathrm{MPa})$ & 92 & 92 & 139 & 187 \\
\hline$k(\mathrm{MPa})$ & 92 & 222 & 295 & 394 \\
\hline$p_{c_{\max }}(\mathrm{MPa})$ & 0.44 & 0.44 & 0.66 & 0.88 \\
\hline$p_{s_{\max }}(\mathrm{MPa})$ & - & 0.07 & 0.08 & 0.16 \\
\hline
\end{tabular}

* JHPC : Japan Highway Public Corporation

$\phi$ の值からモール・クーロン式で算定した.

岩盤の特性曲線を解析するための物性值を Table 3 に 示す. 塑性パラメーター $\alpha, f, h$ の值は, 3. で述べた理 由によって定めた。 また, トンネル半径 $r_{i}$ は, 道路公 団および JR の定める標準断面のうち，最大のものの上 半断面積を円形換算した時の半径とした.

一方，支保の剛性は次式で求める.

$k=k_{s}+k_{c}$

$k_{s}=\frac{E_{s} \cdot A_{s}}{s \cdot r_{i}}$

$$
k_{c}=\frac{E_{c}\left\{r_{i}^{2}-\left(r_{i}-t_{c}\right)^{2}\right\}}{\left(1+\nu_{c}\right)\left\{\left(1-2 \nu_{c}\right) r_{i}^{2}+\left(r_{i}-t_{c}\right)^{2}\right\}} .
$$

ここに, $k$ : 支保の剛性, $k_{s}$ : 鋼ア一チ支保の剛性, $k_{c}$ : 吹付けコンクリートの剛性, $E_{s}$ : 鋼アーチの弾性係 数 (=206 GPa), $A_{s}$ : 鋼アーチの断面積, $s$ : 鋼アーチ の設置間隔, $r_{i}$ : トンネル半径, $E_{c}$ ：欦付けコンクリー トの弾性係数, $\nu_{c}$ : 吹付けコンクリートのポアソン比, $t_{c}$ : 吹付けコンクリートの厚さである.

吹付けコンクリートの弾性係数 $E_{c}$ については, 片瀬 ほか ${ }^{251}$, 土屋 ${ }^{26)}$ な゙の研究がある. 彼らの研究結果を参 考にして $E_{c}=3500 \mathrm{MPa}$ とする. また， $\nu_{c}=1 / 6=0.17$ とする，なお，ロックボルトについては，計算を省略す る.

次に, 極限支保圧力, すなわち支保が負担しうる最大 支保圧力は，次式で求める.

$$
p_{c \max }=\frac{1}{2} \sigma_{c \text { conc }}\left\{1-\frac{\left(r_{i}-t_{c}\right)^{2}}{r_{i}^{2}}\right\}
$$

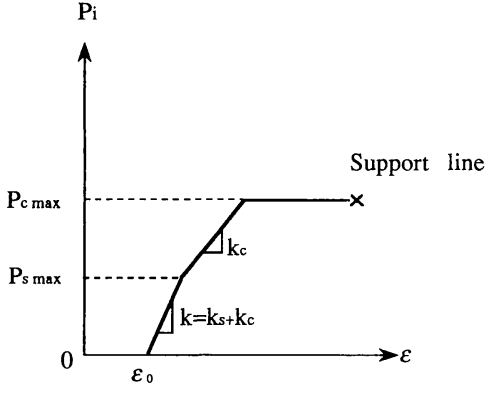

Fig.18 Support line

$$
p_{s \max }=\frac{3 E_{s} \cdot I_{s}}{s \cdot r_{i}{ }^{3}}
$$

ここに, $p_{c \max }$ ：吹付けコンクリートの極限支保圧力, $\sigma_{c \text { conc }}$ : 吹付けコンクリートの圧縮強度, $p_{s \max }$ : 鋼ア一 チの極限支保圧力, $I_{s}$ : 鋼ア一チの断面 2 次モーメント である. なお実績に基づいて $\sigma_{c \text { conc }}=18 \mathrm{MPa}$ とする. 式（39）（43）によって支保剛性と極限支保圧力を計算 した結果を Table 3 に示す.

支保の剛性および極限支保圧力については次のように 考える. すなわち，鋼ア一チと吹付けコンクリートの極 限支保圧力を比べると一般に鋼ア一チの方が小さいの で, 支保圧力が $p_{s \max }$ 以下の場合には，支保の剛性は式 （39）で表される合成支保剛性 $k$ を考えるものとする. 支保圧力が $p_{s \max }$ 以上, $p_{c \max }$ 以下の場合には, 鋼ア一チ はすでに極限に達したものとみなして，支保の剛性は吹 付けコンクリートの剛性 $k_{c}$ のみと考える. 支保圧力が $p_{c \max }$ 以上の場合には, 吹付けコンクリートも極限に達 したものと考え, 極限支保圧力以上にはならず一定值と なり，ひずみだけが増大するものと考える. Fig.18に これらの関係（支保曲線）を示す.

\section{(3) 先行変位}

一般にトンネルにおける計測は, 掘削が終了してから 計器を設置して実施する。したがって, 実際に計測する 変位やひずみは, 計器設置以前に発生している変位（先 行変位）やひずみを含んでいないことになる.

Kitagawa et al. ${ }^{27)}$ は, 泥岩トンネルで先行変位を実 際に計測し, 最終的な収束変位の 12 40\%, 平均で $30 \%$ であったと報告している. また谷本ほか ${ }^{28)}$ は, 同様の計 測から 20〜30\% の先行変位を確認している.

これらのこよより，ここでは先行変位を収束変位の $30 \%$ と仮定して解析を進めるものとする.

\section{(4) 解析結果}

以上述べた岩盤物性值と支保剛性および先行変位の仮 定を用いて, 2. で述べた解析方法に従って計算を行った. 一つの計算例を示すと次のようである.

まず，Table 3 に示す物性值を用いて岩盤の特性曲線 を描く (Fig.19の実線). 次に, Table 3 に示す支保剛 


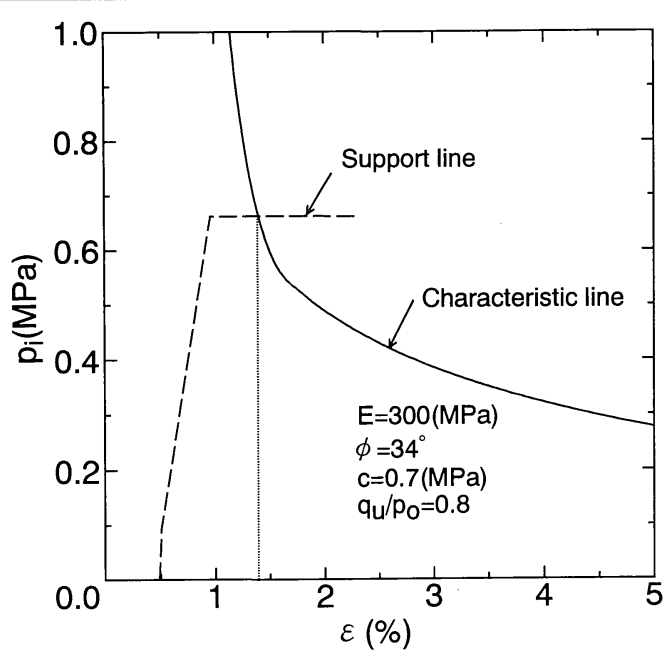

Fig.19 Theoretical analysis

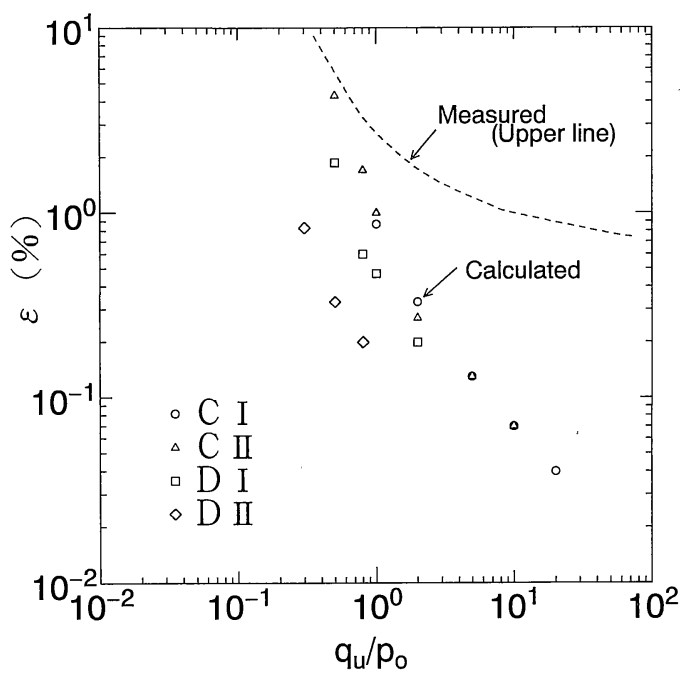

Fig.20 Comparison of calculated-and measured strain

性を用いて支保曲線を描く.この時, 特性曲線亡支保曲 線の交点のひずみ，すなわち収束ひずみの $30 \%$ が支保 曲線の先行ひずみとなるように, 支保曲線を描く (Fig.19 の破線). Fig.19 の例ではひずみ約 $1.4 \%$ でバランスす ることになる。このような計算を地山強度比を変えて夷 施し, 結果をプロットしたのがFig.20である.やはり, 地山強度比が $1.0 \sim 2.0$ を下まわるとひずみ $\varepsilon(=$ $\left.-u_{i} / r_{i}\right)$ が増加する傾向が見られる. Fig.20には, Fig.17で示した計測データの上限值も描いてある. 理 論解析值は，計測データと定性的に概ね良い一致が見ら れ，本解析方法の妥当性が検証できたと考えられる.

\section{5. 結 論}

本報文では，軟岩トンネルの変形挙動を知るために，
ひずみ軟化特性とモール・クーロンの破壊基準を考慮し た特性曲線法を理論展開し, 考察を加えた. その結果, 次の知見が得られた.

1）軟岩のダイレイタンシー特性には，拘束圧依存性 が認められる。

2）一軸圧縮強度あるいは地山強度比が同じでも，そ れを構成する粘着力と内部摩擦角の組合せが，岩盤の変 形挙動に大きく影響する.

3）実際のトンネルで計測されたひずみの最大值は, 地山強度比が $1.0 \sim 2.0$ を下まわると急激に増大する傾 向が認められる.

4）理論解析で得られた值は，実際のトンネルの計測 データを概ね説明しうる.

\section{参 考 文 献}

1) Daemen, J.J.K. : Tunnel support loading caused by rock failure, Technical Report MRD-3-75, U.S. Corps of Engineers, 1975.

2) Terzaghi, K. : Erdbaumechanik auf Bodenphysikalischer Grundlage, Franz Deuticke, pp.212 214, 1925.

3) Fenner, R. : Untersuchungen zur Erkenntnis des Gebirgsdruckes, Glückauf, Vol.74, pp.681 695 and pp.705 715, 1938.

4) Pacher, F. : Measurements of deformation in a test gallery as a means of investigating the behaviour of the rock mass and of specifying lining requirements, Felsmechanik und Ingenieurgeologie, Suppl. 1, pp.148 161, 1964.

5) Rabcewicz, L.v. : The New Austrian Tunnelling Method, Water Power, pp.453 457, Nov. 1964, pp.511 515, Dec. 1964, pp.19 24, Jan. 1965.

6) 岡行俊: 薄肉理論とその応用 $(1),(2)$, トンネルと地 下, 第 7 巻 4 号, pp.227 234, 第 7 巻 5 号, pp. 295 300, 1976年 4 月, 5 月.

7) Kastner, H. : Statik des Tunnel- und Stollenbaues, Springer-Verlag, 1971. [訳] 金原弘：トンネルの力学, 森北出版, 1974.

8) Egger, P. : Einfluss des Post Failure Verhältnis von Fels auf den Tunnelausbau, Thèse. Université de Karlsruhe, 1973. [訳]（社）日本トンネル技術協会：トンネル支保工 に及ぼす破壊後の岩盤の影響, 海峡連絡鉄道の技術に関 する文献資料調査報告書, pp. 17 60, 1978 年 3 月.

9) Ladanyi, B. : Use of the long-term strength concept in the determination of ground pressure on tunnel linings, Proc. of the 3rd Congress of ISRM, Vol.2, Part B, pp.1150 1156, 1974.

10) Hoek, E. and Brown, E.T. : Underground Excavations in Rock, The Institution of Mining and Metallurgy, London, England, 1980. [訳] 小野寺透 - 吉中龍之進 - 斉藤正忠 · 北川隆：岩盤地下空洞の設計と施工, 土木工学社, 1985 .

11) Kaiser, P.K. : A new concept to evaluate tunnel performance-influence of excavations procedure, Proc. of the 22nd U.S. Symposium on Rock Mechanics, pp.284 291, 1981.

12) Brown, E.T., Bray, J.W., Ladanyi, B. and Hoek, E. : 
Ground response curves for rock tunnels, Journal of Geotechnical Engineering, ASCE, Vol.109, No.GE1, pp.15 39, Jan. 1983.

13）土山茂希・入川誠・河田孝志・熊坂博夫：NATM の設計 における理論解の適用, 土木学会第 41 回年次学術講演会, pp. 743〜744, 1986.

14）北川隆：岩盤分類と岩盤-支保相互作用解析，第 19 回岩 盤力学に関するシンポジウム, 土木学会, pp. 281 285, 1987.

15）佐藤正彦・安川正春・矢野尚彦・条田俊男：能生卜ンネ ルの変位特性と支保効果, トンネルと地下, Vol. 18, No. 9, pp. 733 743, 1987.

16) Hisatake, M., Cording, E.T., Ito, T., Sakurai, S. and Phien-weja, N. : Effects of nonlinearity and strength reduction of rocks on tunnel movements, Rock at Great Depth, Maury \& Fourmaintraux (eds), Balkema, 1989.

17）吉中龍之進・山辺正・清水昭男 - 阿部健一・森田栄治： シルト質軟岩の弾塑性挙動に関する実験的研究，第 16 回 岩盤力学に関するシンポジウム講演論文集, pp. 86〜 90, 1984.

18）稲垣大介：トンネルの地山特性曲線に関する基礎研究, 埼玉大学卒業論文, 1991.

19）吉中龍之進 - 山辺正：軟岩の変形特性について, 埼玉大 学建設系研究報告, No. 11, pp. 65 85, 1981.

20）中村正人：統計分析を用いた掘削管理一北陸自動車道薬師 トンネル, トンネルと地下, 第 17 巻 3 号, pp. 185 192,
1986 年 3 月.

21）北川隆・条田俊男・一條俊之・兽我誠意：能生トンネル におけるトンネル先行変位の考察, 西松建設技報, Vol.12, 1989.

22）日本道路公団：設計要領 第三集，トンネル編， 1985.

23）菊地宏吉：ダムを対象とした岩盤分類, 岩盤分類とその 適用, pp. 39 61, 土木工学社, 1989.

24）瀬崎満弘：トンネル設計におけるデータベースの活用と 吹付けコンクリートの硬化特性を考慮した設計・施工に 関する研究, 学位論文.

25）片瀬貴文・谷本親伯・石倉優：シュミットハンマーによ る吹き付けコンクリートの早期強度判定, トンネルと地 下，第 15 巻 2 号, pp. 91 98, 1984 年 2 月.

26）土屋敬：トンネル設計のための支保と地山物性値に関す る研究，土木学会論文集，第 364 号，pp. $31 \sim 40,1985$ 年 12 月.

27) Kitagawa, T., Kumeta, T., Ichizyo, T., Soga, S., Sato, M. and Yasukawa, M. : Application of Convergence Confinement Analysis to the study of preceding displacement of a squeezing rock tunnel, Rock Mechanics and Rock Engineering, Vol.24, No.1, pp.31 51, 1991.

28）谷本親伯・畠昭治郎：切羽周辺での地山挙動を考慮した トンネル支保の基本的概念, 土木学会論文報告集, 第 325 号, pp. 93 106, 1982 年 9 月.

(1992.6.15 受付)

\section{DEFORMATIONAL BEHAVIOR OF SURROUNDING SOFT ROCK MASS IN TUNNELLING}

Takashi KITAGAWA, Daisuke INAGAKI

A theoretical elasto-plastic analysis for determining the deformation of surrounding soft rock mass in tunnelling is discussed. The deformational characteristics of soft rock mass are assumed to be strain-softening model followed by the residual condition. Mohr-Coulomb's failure criterion is employed. The combination of cohesion and friction angle of the rock mass is revealed to be most important factor for the deformational behavior of it. Many measured strains in soft rock tunnels are examined. The theoretically calculated strains agree with the measured strains in general. 